\title{
IDENTIFICATION OF SECTORAL LOGISTICS SERVICE QUALITY GAPS BY APPLYING SERVQUAL METHOD
}

\author{
Ieva MEIDUTE்-KAVALIAUSKIENE $\dot{1}^{1 *}$, Virgilija VASILIENĖ-VASILIAUSKIENÉ², \\ Aidas VASILIS VASILIAUSKAS ${ }^{3}$ \\ ${ }^{1,3}$ General Jonas Žemaitis Military Academy of Lithuania, Vilnius, Lithuania \\ ${ }^{2}$ Dept of Logistics and Transport Management, Vilnius Gediminas Technical University, Vilnius, Lithuania
}

Received 26 November 2019; revised 12 May 2020, 22 June 2020; accepted 3 July 2020

\begin{abstract}
Today, simply delivering a product to the right place at the right time is no longer enough. Customers demand more; they demand the full suite of logistics services. Customers thus seek higher-value and additional services, and more, which enable them to compete. Thus, the problem underlying analysis is customers' growing dissatisfaction with existing services and their quality. Quality of service no longer gives business entities a competitive edge. It is vital for companies to have different activities, to operate in different branches of the economy, and to work with different types of goods. However, despite these differences, they all want to obtain maximum satisfaction from logistics services. With this in mind, the purpose of this article is to present a study examining the impact of logistics service quality on the satisfaction of companies working with different categories of goods Results indicated that different logistics service users do not have the same requirements for logistics service quality. Moreover, it was proved that SERVQUAL method is suitable for identification of sectoral value gaps, which can be applied in practice assuring competitive advantage.
\end{abstract}

Keywords: logistics, service, quality, SERVQUAL, transport company, concept, model.

\section{Introduction}

In the current business world, providing high-quality services are one of the key factors in staying in the market. Since the survival of a business depends on customers using that business's services, it is important to give customers what they want. Thus, the service provided must meet customer expectations.

At this time, there is an observable trend of declining client loyalty to one business entity. Clients these days are always looking for new, better business entities that can meet the ever-growing demands of their needs. These ever-growing customer expectations include various aspects: benefits and value for money, as well as the quality the customer seeks from the product or service. Therefore, businesses must be constantly aware of customer expectations, adapting to them, and able to meet them. The question is how to satisfy customers and meet their expectations at the lowest cost while maintaining a strong market position - a competitive advantage.

The purpose of this article is to present a study examining the impact of logistics service quality on the satisfaction of companies working with different categories of goods. This research applies the methods of literary analysis and synthesis, and it utilizes the SERVQUAL model.

The remainder of the paper is organized as follows. The next section looks at the analysis of scientific approaches to logistics services and using the SERVQUAL model to evaluate the quality of logistics services. The subsequent section presents the methodological background of the study, explains the procedural steps followed in the construction of our framework, and presents the results found.

\section{Literature review}

\subsection{Analysis of scientific approaches to logistics services}

It is no doubt that service quality in logistics is very important topic addressed in huge amount of scientific papers (Anderson et al. 1994; Franceschini, Rafele 2000; Kaynak 2003; Rahman 2006; Feng et al. 2007; Ganesan-Lim et al. 2008; Hong, Lyong 2008; Baki et al. 2009; Juga et al. 2010;

${ }^{\star}$ Corresponding author. E-mail: ieva.meidute@lka.lt 
Kersten, Koch 2010; Huang et al. 2012; Jia et al. 2013; Aggarwal et al. 2014; Prentkovskis et al. 2018; Zanjirani et al. 2019). These authors come to a conclusion that service quality is main prerequisite to develop a successful business. Providing quality services is an opportunity to meet customer expectations and gain a competitive advantage in the market (Kaynak, Hartley 2008; Choudhury 2015; Subramanian et al. 2016). However, the concept of quality in logistics services is becoming more complex, which means that a high-quality product and a good marketing strategy are no longer sufficient (Grönroos 1984). As reported by Mentzer et al. (2001), Rahman (2006), Feng et al. (2007) and Agnihotri et al. (2016), high-quality services and continuously monitoring parameters that determine quality can improve a company's ability to meet their customers' expectations by the value created for them. The value created through logistics services is based on the customer's perceived gap between the quality of service provided and the quality of service that the customer expects (Ferreira et al. 2015; Blut et al. 2015; Agnihotri et al. 2016; Cepeda-Carrion et al. 2017; Al-Jazzazi, Sultan 2017). The smaller this gap, the greater the perceived value (Chen, C.-F., Chen, F.-S. 2010). Thus, if the quality of service the company provides meets (or exceeds) the quality of service that the customer desires and receives, the value perceived by the customer is fulfilled.

Neo et al. (2004) state that value is created when a logistics service provider can implement the principle of the 5Rs (Five Rights) or 7Rs (Seven Rights): deliver the right item, in the right quantity, to the right place, at the right time, to the right/correct customer, in the right/ proper condition (quality), at the right/fair price. Fulfilling requirements in the provision of logistics services creates high added value. However, there are some negative aspects, as well. One example is the relationship between business partners. According to Tate (1996), traditional business-to-business relationships in the markets are transaction-based (often per transaction), while partnership-based (long-term) relationships include sharing benefits and operational intelligence, advanced planning, and easier control. In the field of logistics, it is often the case that only one or several logistics services are outsourced, rather than the whole complex. In addition, different services may be outsourced from different service providers. As a result, many transactions take place; controlling them is more complex, more time-consuming, and so on. The effectiveness of such individual services is also difficult to evaluate. As a result, there is a growing tendency to choose an entire logistics service complex from one specialized supplier (Neo et al. 2004). That supplier is expected to create overall value and value in all of the separate elements of services.

Evaluating (Kim et al. 2012) and measuring (Bienstock et al. 1997) the quality of logistics services itself is quite complex. There are numerous logistics services, so there are many criteria for measuring them, as well. It is particularly difficult to assess the overall quality of ser- vice when using different service providers. According to Caplice and Sheffi (1995), logistics involve a complex of logistics activities and require a group of indicators that show the appropriate level of operational performance to measure them. Ideally, all indicators should be selected and managed as a single common framework. The results obtained in that manner may be complementary and mutually supportive, providing a coherent overall picture of the performance quality of the logistics service provider of their choice.

Franceschini, Rafele (2000) and Chen et al. (2009) state that there is a need to define a set of quality indicators in order to evaluate the quality of logistics service. They provide a "classic" set of indicators describing the quality of the logistics service. In their view, eight indicators are needed to measure the quality of logistics services: time, regularity, reliability, completeness, flexibility, fairness, harmlessness, and productivity. These indicators can be further subdivided.

Lao et al. (2011) provide another set of performance indicators that they claim may influence service quality. They identified 11 performance measurement groups (delivery timeliness, cost, total quality, inventory management, assembly accuracy, responsiveness and flexibility, error and damage assessment, time needed to accomplish a new production order, receipt/unloading and dispatch/ loading, documentation management, etc.). Banomyong and Supatn (2011) analyse service quality criteria primarily related to order processing: information quality, order process, order release volume, timeliness, order accuracy, order quality, order conditions, order mismatch management, quality of staff availability.

There are many varied sets of parameters by which performance or quality of service can be assessed. Therefore, to evaluate the overall quality of logistics services, it is appropriate to group them together and consider them as a whole.

Another problem area related to service quality assessment is that in practice, only the quality of the service (perceived quality) being performed (or already performed) is usually evaluated. Meanwhile, the customer's expectations (expected quality) for a service remain unclear. Thus, the logistics service provider knows its performance level, but the provider does not know the initial factor - customer expectations. The service is provided in the way that its provider believes is best. These activities are in the reverse order. In general, quality is perceived subjectively, which makes the process of measuring quality difficult (An 2004; Hong, Lyong 2008; Huang et al. 2012; Agnihotri et al. 2016).

\subsection{Analysis of SERVQUAL model application in logistics}

The SERVQUAL model is used to measure and evaluate the quality of service in logistics. It is a multi-item questionnaire designed to measure customer expectations and determine customer perception of the quality of service 
they receive. Its findings reveal the gap between how and to what extent the customer's perception of service quality differs from what the customer expects from the service provider. At the same time, the most relevant factors in assessing the service provider and the quality of his service are identified.

The five factors of this model are: tangibles, reliability, responsiveness, assurance, and empathy. These factors are the tools that determine how service quality is measured, as well as service quality. A significant advantage of the model is that not only is the customer's perception is identified based on the SERVQUAL questionnaire, but their expectations are also illuminated (Babakus, Boller 1992; Ciavolino, Calcagnì 2015).

Numerous published research papers exist (An 2004; Hong, Lyong 2008; Campos, Nóbrega 2009; Dahlgaard-Park, Dahlgaard 2010; Kansra, Jha 2016; Ali, Raza 2017; İnan et al. 2017) showing examples of SERVQUAL model adaptations. However, few studies use the SERVQUAL model for logistics (especially 3PL) service quality assessment (Franceschini, Rafele 2000; An 2004; Ahn et al. 2008; Pantouvakis et al. 2008; Baki et al. 2009; Kersten, Koch 2010; Kilibarda et al. 2012; Banomyong, Supatn 2011). This is especially the case when the quality of service is also linked to measuring customer satisfaction.

Pantouvakis et al. (2008) conducted a study aimed at determining whether the SERVQUAL model can be adapted to evaluate the perception of service quality in shipping. Based on the results obtained, the SERVQUAL model has been shown to be an effective instrument for measuring the quality of passenger transportation. Moreover, these authors aimed to find out whether it is possible to evaluate the overall perceived customer satisfaction by using the SERVQUAL model. The results showed that three factors of the SERVQUAL model (reliability, assurance, and empathy) do not seem statistically significant. The other two factors, Tangibles and Responsiveness, not only provide a slightly better explanation of customer satisfaction from the standpoint of sea-ports, but they are also statistically significant. Consequently, tangibles and responsiveness are important factors for the user when assessing the quality of service.

Franceschini and Rafele (2000) applied the SERVQUAL model ale to evaluate logistics services. In this study, traditional logistics indicators were first compared to a set of parameters specific to a particular leader in the logistics sector. Then, the relationships between the model set of indicators for measuring the quality of service and the factors characterizing the quality of service were investigated. Comparing these indicators showed that empathy does not generally appear in relation to any of the indicators, though in some situations, this factor's influence is very important.

Banomyong and Supatn (2011) conducted a study to illuminate the "key" criteria that determine the quality of a logistics service; they later evaluated the impact of each criterion in choosing a 3PL service provider. The results showed that reliability and assurance are significantly related to the choice of a 3PL service provider. The most significant criterion was accuracy of documents, followed by these criteria in order of greatest to least importance: (1) providing renewable freight rates, (2) good customer service, (3) providing e-services, (4) offering consolidation services. Exporters consider accuracy of documents to be the most relevant criterion, as the documents issued by the service provider are used as formal proof of the international payment of goods, and any discrepancy would delay payment. In addition, discrepancies may result in additional charges on unpaid amounts. Finally, accurate filing and management can facilitate and ensure efficient freight flow management. Thus, these authors identified reliability as the most significant factor in logistics.

Baki et al. (2009) used the SERVQUAL model to evaluate a transport company's quality of service. They found that none of the criteria provided was strong, indicating that all respondents rated the expected quality of service higher than the perceived quality. Such an assessment may be based on ever-increasing customer expectations. Other authors (Ugboma et al. 2007) also found that customer expectations exceeded the perceived (actual) quality of service in terms of all criteria provided. When investigating the quality of service, Ugboma et al. (2007) found that respondents rated responsiveness and tangibles highly and empathy poorly. These authors also investigated the relationship between service quality and customer satisfaction. The results showed a very strong relationship between the core and related dimensions of service quality and satisfaction, i.e., customers who have a positive perception of the quality of service provided tend to be satisfied with the quality of performance given by ports.

In summary, all five factors of the SERVQUAL model are treated differently in different situations (studies). Some criteria are considered to be more important in one case, while other criteria are more relevant in others.

\section{Methodological background}

For the purpose of this research, a research model is created (Figure 1). The diagram depicts the elements to be explored: customer expectations, perceived quality, and customer satisfaction. Customers are categorized according to the type of goods they use. Overall satisfaction is determined, and satisfaction with the quality of logistics services among representatives of customers trading in different categories of goods is compared.

For the purpose of this research, a research model is created (Figure 1). The diagram depicts the elements to be explored: customer expectations, perceived quality, and customer satisfaction. Customers are categorized according to the type of goods they use. Overall satisfaction is determined, and satisfaction with the quality of logistics services among representatives of customers trading in different categories of goods is compared. 


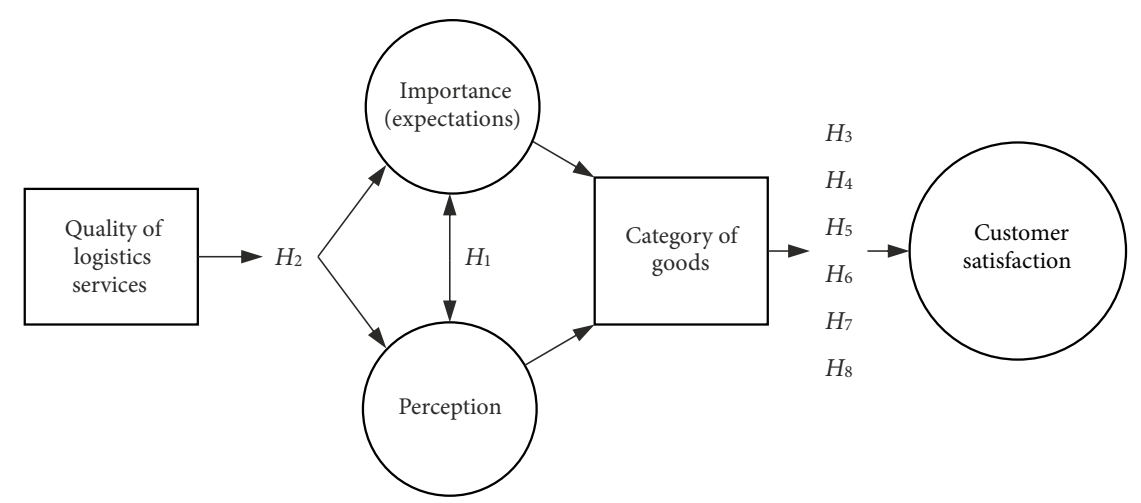

Figure 1. Schematic diagram of the research model (source: compiled by authors)

Research process is based on several hypothesis. The first hypothesis $\left(H_{1}\right.$ - customer expectations are higher than the actual benefits (perception)) is raised to confirm or refute the view that customer expectations outweigh the benefits (quality) actually received from the logistics service provider. Chumpitaz Caceres and Paparoidamis (2007) found that clients with negative perceptions of service delivery tended to increase their expectations by creating a large gap, while those with positive perception tended to lower their expectations by creating a smaller gap between perception and expectation. The authors also state that most studies using the SERVQUAL model have shown that expectations-results rank quite high on the Likert scale. Another hypothesis $\left(\mathrm{H}_{2}-\right.$ reliability has the greatest impact on customer satisfaction compared with the other four factors: tangibles, responsiveness, assurance, and empathy) is raised based on the five dimensions of the SERVQUAL questionnaire. It is formulated so that the investigation will make it possible to determine which factor has the greatest influence on the quality of logistics services, thus confirming that the hypothetical factor has the greatest influence. This hypothesis demonstrates a causal relationship between the five factors on the SERVQUAL model - tangibles, reliability, response, assurance, and empathy, which will later be broken down into 22 qualitative logistics service performance indicators - and overall satisfaction with customer service. Satisfaction is measured by first assessing customer expectations of the logistics provider and then assessing the quality the customer receives. Juga et al. (2010) found that gap analysis using the SERVQUAL instrument provides a useful framework for evaluating the quality of 3PL services.

Despite criticism of the SERVQUAL model's effectiveness across different service areas, splitting the five dimensions of the SERVQUAL into 22 items is appropriate because it is generally agreed that, on this scale, 22 items offers a reasonably good number for evaluating overall service quality (Sureshchandar et al. 2002). The author also claims that the indicators mentioned are primarily related to the human element, manifesting in the service provision, and is based on tangible aspects of the service (for example, elements of design, external appearance/state of equipment, exterior/appearance of employees, etc.).
Franceschini and Rafele (2000) found that, in practice, evaluating the quality of logistics services does not use elements related to Empathy, and the use of Assurance is limited. Pantouvakis et al. (2008) used the SERVQUAL model to study the quality of sea-port services and found that reliability, responsiveness, and tangibles received high ratings, with the lowest rating being empathy. In addition, they found responsiveness to be less correlated with overall customer satisfaction (meaning it is less significant) than the other four factors in the SERVQUAL model.

Other hypotheses may help answer the question of whether representatives of customers trading in different categories of goods are as well-satisfied (depending on their needs) with the quality of logistics services, and whether the SERVQUAL model's factors have an equal impact on satisfaction among representatives of customers trading in different product categories:

- $\mathrm{H}_{3}$ - representatives of customers trading in different categories of goods are not equally satisfied with the quality of logistics services;

- $\mathrm{H}_{4}$ - representatives of customers trading in different categories of goods are not equally satisfied with the quality of the tangibles factor;

- $\mathrm{H}_{5}$ - representatives of customers trading in different categories of goods are not equally satisfied with the quality of the reliability factor;

- $\mathrm{H}_{6}$ - representatives of customers trading in different categories of goods are not equally satisfied with the quality of the responsiveness factor;

- $\mathrm{H}_{7}$ - representatives of customers trading in different categories of goods are not equally satisfied with the quality of the assurance factor;

- $\mathrm{H}_{8}$ - representatives of customers trading in different categories of goods are not equally satisfied with the quality of the empathy factor.

One of the research methods, quantitative research, will help confirm or refute the hypotheses, meeting the purpose of the study. Respondents selected for the survey are Lithuanian companies (149) that handle different types of goods and use logistics services, meaning they entrust logistics operations to logistics companies. Based on the experience of researchers Banomyong, Supatn (2011); Pla- 
koyiannaki, Zotos (2009); Mckinnon et al. (2007), three product groups have been chosen:

- everyday consumer goods (food, drink, clothing, household, etc.);

- luxury goods (household and computer equipment, etc.);

- construction and raw materials.

These groups of goods are quite large, contain a number of similar goods in one category, and are quite different from one another. It is believed that a greater disaggregation of commodity groups would make the differences between them less significant, while having smaller quantities and larger groups is expected to help achieve bigger differences.

A questionnaire was made to investigate the service quality of Lithuanian logistics companies. It is based on the main part of the SERVQUAL model, relying on the suitability of this scale as identified in the literature analysis. Chumpitaz Caceres and Paparoidamis (2007) found that the dimensions of the SERVQUAL model are not generic and must be tailored to a specific domain. The questionnaire consists of five parts. The first part determines whether the customer uses the services of any logistics companies at all, followed by common questions about logistics services outsourced by customers. The second part is designed to set the expectations of customers using logistics companies. The third part helps determine the customer's perception of the quality of the logistics service. The SERVQUAL model is used to measure cus- tomer expectations and perceptions. Each part contains 22 statements each.

As with any survey, this questionnaire has limitations. Surveys using the SERVQUAL template are long and thus less appealing to respondents than short questionnaires. Not all respondents willingly complete the questionnaire. The number of respondents surveyed, based on the estimated sample size, does not fully represent the entire population. There is a small number of companies providing a full set of logistics services in Lithuania. Service is a variable phenomenon, not a homogeneous one; studying the quality of services in a certain period cannot fully account for the quality of a continuous process and instead reflects only the current situation.

\section{Analysis of survey data on logistics service quality}

\subsection{General analysis of respondents' data}

According to the survey, $73.1 \%$ of all participating companies hire logistics services, and $25 \%$ have their own logistics department but also hire logistics services from other companies. All respondents are included in the number of enterprises analysed. Only $19.8 \%$ of respondents buy 3PL services. Some $79 \%$ of respondents use the services of various logistics service providers. General information on the respondents in the survey is presented in Table 1.

The percent of respondents by commodity category is as follows: the largest commodity category was food

Table 1. General information about survey respondents (source: compiled by authors)

\begin{tabular}{|c|c|c|c|c|c|}
\hline \multicolumn{3}{|l|}{ Business location in the supply chain } & \multicolumn{3}{|c|}{ How many employees work at your company? } \\
\hline Manufacturer & 33 & $21.7 \%$ & $0 \ldots 4$ employees & 22 & $14.5 \%$ \\
\hline Driver & 4 & $2.6 \%$ & $5 . . .9$ employees & 31 & $20.4 \%$ \\
\hline Supplier & 36 & $23.7 \%$ & $10 \ldots 49$ employees & 66 & $43.4 \%$ \\
\hline Retailer & 22 & $14.5 \%$ & $50 . .249$ employees & 24 & $15.8 \%$ \\
\hline Wholesaler & 49 & $32.2 \%$ & 250 employees or more & 9 & $5.9 \%$ \\
\hline Service recipient (user) & 5 & $3.3 \%$ & \multirow[t]{3}{*}{ Total answers } & \multirow[t]{3}{*}{152} & \\
\hline Other & 3 & $2 \%$ & & & \\
\hline Total answers & 152 & & & & \\
\hline \multicolumn{3}{|l|}{ Most frequently outsourced services: } & \multicolumn{3}{|l|}{ Business ownership status } \\
\hline Land transport (road and rail) services & 128 & $84.2 \%$ & Totally local capital & 113 & $74.3 \%$ \\
\hline Air transport services & 11 & $7.2 \%$ & Totally foreign capital & 11 & $7.2 \%$ \\
\hline Water transport services & 13 & $8.6 \%$ & United (both local and foreign capital) & 28 & $18.4 \%$ \\
\hline \multirow[t]{2}{*}{ Total answers } & \multirow[t]{2}{*}{152} & & Other & 0 & $0 \%$ \\
\hline & & & Total answers & 152 & \\
\hline \multicolumn{3}{|l|}{ Responsibilities } & & & \\
\hline Manager & 73 & $48 \%$ & & & \\
\hline Project manage; & 22 & $14.5 \%$ & & & \\
\hline Manager/director & 36 & $23.7 \%$ & & & \\
\hline General manager & 7 & $4.6 \%$ & & & \\
\hline Other & 14 & $9.2 \%$ & & & \\
\hline Total answers & 152 & & & & \\
\hline
\end{tabular}


and beverage companies (13.8\%), followed by representatives of other product categories (12.5\%); representatives working with luxury goods $(11.8 \%)$; businesses working with daily consumer goods (10.5\%), and companies working with construction materials (9.2\%). The other most common product categories were household appliances, household goods, medical supplies, and agricultural machinery. The product categories belonging to the product groups analysed from the list of "others" could be included in the analysis, but due to the statistical complexity, the response category of "other" was removed from the analysis.

The majority of companies participating in the survey are wholesalers $(32.2 \%)$. The main mode of transportation used the most in Lithuania is by land, used by $84.2 \%$ of respondents. Most of the companies are local capital (74.3\%) that employ $10 \ldots 49$ people $(43.4 \%)$. In terms of role at the company, it was usually the manager who answered the questionnaire (48\%).

\subsection{Analysis of expectations and perception}

The results of the survey on respondents' expectations and the current evaluation of logistics service quality (perception) are presented in Table 2 . The rating on a 5-point Likert scale ranges from 1 point (not at all important or very bad) to 5 points (very important or very good). The following table provides the mean values (descriptive) for each statement from all respondents, the sum of these mean values, the means, and the size of the gap between perception and expectation. The gap is derived from the perception values minus the expectation values.

Table 2. Mean values of expectations, perception, and gaps (source: compiled by authors)

\begin{tabular}{|c|c|c|c|c|}
\hline \multirow{2}{*}{\multicolumn{2}{|c|}{ Criterion }} & \multicolumn{3}{|c|}{ Mean values } \\
\hline & & $\begin{array}{l}\text { Expectation } \\
\text { mean }\end{array}$ & $\begin{array}{l}\text { Perception } \\
\text { mean }\end{array}$ & Gap \\
\hline \multicolumn{5}{|c|}{ Tangibles } \\
\hline$V_{1}$ & well-maintained, cutting-edge equipment & 3.48 & 3.37 & -0.11 \\
\hline$V_{2}$ & comfortable working environment and infrastructure & 3.07 & 3.23 & 0.16 \\
\hline$V_{3}$ & neat, professional-looking staff & 3.00 & 3.37 & 0.37 \\
\hline$V_{4}$ & clear and correct company documents & 4.64 & 3.72 & -0.92 \\
\hline & In total & 14.19 & 13.69 & -0.50 \\
\hline & Criterion average $(=$ total / 4) & 3.55 & 3.42 & -0.13 \\
\hline \multicolumn{5}{|c|}{ Reliability } \\
\hline$V_{5}$ & delivering the logistics service as promised & 4.91 & 3.42 & -1.49 \\
\hline$V_{6}$ & sincere employee involvement in addressing customer problems & 4.40 & 3.58 & -0.82 \\
\hline$V_{7}$ & performing the service well the first time & 4.78 & 3.26 & -1.52 \\
\hline$V_{8}$ & service performance within the scheduled timeframe & 4.79 & 3.30 & -1.49 \\
\hline$V_{9}$ & presentation of documents, records, and other information with no errors & 4.72 & 3.93 & -0.79 \\
\hline & In total & 23.60 & 17.49 & -6.11 \\
\hline & Criterion average $(=$ total / 5) & 4.72 & 3.50 & -1.22 \\
\hline \multicolumn{5}{|c|}{ Responsiveness } \\
\hline$V_{10}$ & $\begin{array}{l}\text { providing information to customers on the progress of the service / service } \\
\text { already performed }\end{array}$ & 4.23 & 3.46 & -0.77 \\
\hline$V_{11}$ & fast, accurate customer service & 4.61 & 3.41 & -1.20 \\
\hline$V_{12}$ & staff readiness and willingness to provide services & 4.35 & 3.67 & -0.68 \\
\hline$V_{13}$ & staff readiness to respond to customer requests & 4.47 & 3.66 & -0.81 \\
\hline & In total & 17.66 & 14.20 & -3.46 \\
\hline & Criterion average $(=$ total / 4$)$ & 4.42 & 3.55 & -0.87 \\
\hline \multicolumn{5}{|c|}{ Assurance } \\
\hline$V_{14}$ & the ability of employees to build trust with customers & 4.02 & 3.48 & -0.54 \\
\hline$V_{15}$ & the ability of employees to make their clients feel comfortable & 3.68 & 3.46 & -0.22 \\
\hline$V_{16}$ & consistent politeness from company employees & 3.77 & 3.68 & -0.09 \\
\hline$V_{17}$ & qualified staff that can answer all customer questions & 4.34 & 3.48 & -0.86 \\
\hline & In total & 15.81 & 14.10 & -1.71 \\
\hline & Criterion average $(=$ total / 4) & 3.95 & 3.53 & -0.43 \\
\hline \multicolumn{5}{|c|}{ Empathy } \\
\hline$V_{18}$ & company's individual attention to customers & 4.11 & 3.58 & -0.53 \\
\hline$V_{19}$ & employee's personalized services and attention to their clients & 4.09 & 3.53 & -0.56 \\
\hline$V_{20}$ & employee's focus on customer interest & 4.38 & 3.33 & -1.05 \\
\hline$V_{21}$ & employee's understanding of customer needs & 4.48 & 3.22 & -1.26 \\
\hline$V_{22}$ & logistics company's working hours & 4.23 & 3.72 & -0.51 \\
\hline & In total & 21.29 & 17.38 & -3.91 \\
\hline & Criterion average $(=$ total / 5) & 4.26 & 3.48 & -0.78 \\
\hline
\end{tabular}


By comparing expectations and perception of all statements, we see that the customer perception of logistics companies is lower than the expectations for 20 of the statements (the values are negative). Since the perception of most claims was ranked lower than the expectations, it is possible to confirm the first hypothesis $\left(H_{1}\right)$, which states that the expectations of logistics enterprises' customers are higher than the actual benefit they receive.
For each SERVQUAL criterion statement, the mean values of the expectations and perceptions of companies working with the selected product categories (everyday consumer goods, luxury goods, and construction and other raw materials) are presented in Table 3. The first column shows the mean values of expectations for companies in the everyday consumer goods category; the second column shows their current quality of logistics services.

Table 3. Mean values of expectations and perceptions of businesses dealing in everyday consumer goods, luxury goods, and construction and other raw materials (source: compiled by authors)

\begin{tabular}{|c|c|c|c|c|c|c|c|}
\hline & \multirow{3}{*}{ Criterion } & \multicolumn{6}{|c|}{ Mean values } \\
\hline & & \multicolumn{2}{|c|}{$\begin{array}{l}\text { Everyday consumer } \\
\text { goods }\end{array}$} & \multicolumn{2}{|c|}{ Luxury goods } & \multicolumn{2}{|c|}{$\begin{array}{l}\text { Construction and } \\
\text { other raw material }\end{array}$} \\
\hline & & $\begin{array}{l}\text { Expec- } \\
\text { tation }\end{array}$ & $\begin{array}{l}\text { Percep- } \\
\text { tion }\end{array}$ & $\begin{array}{l}\text { Expec- } \\
\text { tation }\end{array}$ & $\begin{array}{l}\text { Percep- } \\
\text { tion }\end{array}$ & $\begin{array}{c}\text { Expec- } \\
\text { tation }\end{array}$ & $\begin{array}{l}\text { Percep- } \\
\text { tion }\end{array}$ \\
\hline \multicolumn{8}{|c|}{ Tangibles } \\
\hline$V_{1}$ & well-maintained, cutting-edge equipment & 3.77 & 3.56 & 3.95 & 3.00 & 2.78 & 3.38 \\
\hline$V_{2}$ & comfortable working environment and infrastructure & 3.33 & 3.44 & 3.49 & 2.92 & 2.43 & 3.33 \\
\hline$V_{3}$ & neat, professional-looking staff & 3.19 & 3.54 & 3.26 & 3.13 & 2.40 & 3.40 \\
\hline$V_{4}$ & clear and correct company documents & 4.58 & 3.77 & 4.85 & 3.41 & 4.53 & 3.95 \\
\hline & In total & 14.84 & 14.31 & 15.55 & 12.46 & 12.14 & 14.06 \\
\hline & Criterion average $(=$ total $/ 4)$ & 3.72 & 3.58 & 3.89 & 3.12 & 3.04 & 3.51 \\
\hline \multicolumn{8}{|c|}{ Reliability } \\
\hline$V_{5}$ & delivering the logistics service as promised & 4.90 & 3.44 & 4.97 & 3.15 & 4.83 & 3.45 \\
\hline$V_{6}$ & $\begin{array}{l}\text { sincere employee involvement in addressing customer } \\
\text { problems }\end{array}$ & 4.40 & 3.46 & 4.59 & 3.59 & 4.23 & 3.65 \\
\hline$V_{7}$ & performing the service well the first time & 4.75 & 3.06 & 4.87 & 3.18 & 4.80 & 3.35 \\
\hline$V_{8}$ & service performance within the scheduled timeframe & 4.83 & 3.13 & 4.77 & 3.23 & 4.75 & 3.28 \\
\hline$V_{9}$ & $\begin{array}{l}\text { presentation of documents, records, and other } \\
\text { information with no errors }\end{array}$ & 4.77 & 4.00 & 4.74 & 3.97 & 4.70 & 3.73 \\
\hline & In total & 23.65 & 17.09 & 23.94 & 17.12 & 23.31 & 17.46 \\
\hline & Criterion average $(=$ total / 5) & 4.73 & 3.42 & 4.79 & 3.43 & 4.66 & 3.49 \\
\hline \multicolumn{8}{|c|}{ Responsiveness } \\
\hline$V_{10}$ & $\begin{array}{l}\text { providing information to customers on the progress } \\
\text { of the service / service already performed }\end{array}$ & 4.15 & 3.40 & 4.49 & 3.46 & 4.25 & 3.65 \\
\hline$V_{11}$ & fast, accurate customer service & 4.75 & 3.40 & 4.51 & 3.44 & 4.68 & 3.30 \\
\hline$V_{12}$ & staff readiness and willingness to provide services & 4.46 & 3.79 & 4.56 & 3.67 & 4.10 & 3.53 \\
\hline$V_{13}$ & staff readiness to respond to customer requests & 4.54 & 3.79 & 4.54 & 3.51 & 4.35 & 3.65 \\
\hline & In total & 17.90 & 14.38 & 18.10 & 14.08 & 17.38 & 14.13 \\
\hline & Criterion average $(=$ total / 4$)$ & 4.48 & 3.59 & 4.53 & 3.52 & 4.35 & 3.53 \\
\hline \multicolumn{8}{|c|}{ Assurance } \\
\hline$V_{14}$ & the ability of employees to build trust with customers & 4.04 & 3.73 & 4.31 & 2.95 & 3.70 & 3.53 \\
\hline$V_{15}$ & $\begin{array}{l}\text { the ability of employees to make their clients feel } \\
\text { comfortable }\end{array}$ & 3.60 & 3.56 & 4.08 & 3.26 & 3.33 & 3.53 \\
\hline$V_{16}$ & consistent politeness from company employees & 3.96 & 3.90 & 3.92 & 3.69 & 3.30 & 3.33 \\
\hline$V_{17}$ & qualified staff that can answer all customer questions & 4.42 & 3.63 & 4.54 & 3.13 & 4.13 & 3.48 \\
\hline & In total & 16.02 & 14.82 & 16.85 & 13.03 & 14.46 & 13.87 \\
\hline & Criterion average (= total / 4$)$ & 4.01 & 3.70 & 4.21 & 3.26 & 3.62 & 3.48 \\
\hline \multicolumn{8}{|c|}{ Empathy } \\
\hline$V_{18}$ & company's individual attention to customers & 4.27 & 3.60 & 4.23 & 3.51 & 3.93 & 3.68 \\
\hline$V_{19}$ & $\begin{array}{l}\text { employee's personalized services and attention to their } \\
\text { clients }\end{array}$ & 4.23 & 3.40 & 4.15 & 3.51 & 4.00 & 3.80 \\
\hline$V_{20}$ & employee's focus on customer interest & 4.63 & 3.13 & 4.36 & 3.21 & 4.23 & 3.55 \\
\hline$V_{21}$ & employee's understanding of customer needs & 4.71 & 3.25 & 4.49 & 2.82 & 4.36 & 3.33 \\
\hline$V_{22}$ & logistics company's working hours & 4.48 & 3.63 & 4.18 & 3.74 & 4.10 & 3.75 \\
\hline & In total & 22.32 & 17.01 & 21.41 & 16.79 & 20.62 & 18.11 \\
\hline & Criterion average $(=$ total / 5) & 4.46 & 3.40 & 4.28 & 3.36 & 4.12 & 3.62 \\
\hline
\end{tabular}


The results for the other two product categories are shown in the same way.

After comparing all three categories of goods, we can see that expectations for reliability are the highest $\left(V_{5} \ldots\right.$ $\left.V_{9}\right)$. Empathy is in second-place $\left(V_{18} \ldots V_{22}\right)$. The least important factor is Tangibles $\left(V_{1} \ldots V_{4}\right)$. The values of the gap between expectations and perceptions are mostly negative, which means that respondents' expectations for most of the criteria on the quality of logistics services exceed the experience they have.

\subsection{Analysis of SERVQUAL model factors by comparable product categories}

Table 3 presents the mean values of the five factors in the SERVQUAL model: tangibles, reliability, responsiveness, assurance, and empathy. Mean values of expectations for representatives of customers trading in everyday consumer goods, luxury goods, and construction and other raw materials are presented, as are mean values of perceptions for representatives of customers trading in everyday consumer goods, luxury goods, and construction and other raw materials categories.
The higher the significance of the expectation assessment, the more important this factor is to the respondent. The greater the value for the perception factor, the higher the respondents consider the quality of logistics services they receive.

The analysis of each statement was aimed at checking whether the expectations of representatives of customers trading in everyday consumer goods, luxury goods, and construction and other raw materials categories differ significantly, to then determine the most significant factors for each of the categories of selected goods. It also examines whether there is a significant difference in the perception of respondents in the categories of the everyday consumer goods, luxury goods, and construction and other raw materials to determine which of the criteria on logistics service quality currently best suits the customer.

Table 4 presents the Sig. value of all the statements (ANOVA - ANalysis Of VAriance) for determining whether the statements are significantly different or not. A Sig. value less than 0.05 indicates a significant difference between the importance of the criteria. A Sig. value greater than 0.05 means that there is no statistically significant difference between the criteria scores.

Table 4. SERVQUAL statements Sig. values (source: compiled by authors)

\begin{tabular}{|c|c|c|c|}
\hline \multirow{2}{*}{\multicolumn{2}{|c|}{ Criterion }} & \multicolumn{2}{|c|}{ Sig. values } \\
\hline & & Expectations & Perception \\
\hline \multicolumn{4}{|c|}{ Tangibles } \\
\hline$V_{1}$ & well-maintained, cutting-edge equipment & 0.000 & 0.004 \\
\hline$V_{2}$ & comfortable working environment and infrastructure & 0.000 & 0.004 \\
\hline$V_{3}$ & neat, professional-looking staff & 0.000 & 0.079 \\
\hline$V_{4}$ & clear and correct company documents & 0.095 & 0.053 \\
\hline \multicolumn{4}{|c|}{ Reliability } \\
\hline$V_{5}$ & delivering the logistics service as promised & 0.461 & 0.113 \\
\hline$V_{6}$ & sincere employee involvement in addressing customer problems & 0.216 & 0.818 \\
\hline$V_{7}$ & performing the service well the first time & 0.367 & 0.192 \\
\hline$V_{8}$ & service performance within the scheduled timeframe & 0.919 & 0.130 \\
\hline$V_{9}$ & presentation of documents, records, and other information with no errors & 0.875 & 0.276 \\
\hline \multicolumn{4}{|c|}{ Responsiveness } \\
\hline$V_{10}$ & providing information to customers on the progress of the service / service already performed & 0.062 & 0.661 \\
\hline$V_{11}$ & fast, accurate customer service & 0.075 & 0.812 \\
\hline$V_{12}$ & staff readiness and willingness to provide services & 0.012 & 0.730 \\
\hline$V_{13}$ & staff readiness to respond to customer requests & 0.348 & 0.519 \\
\hline \multicolumn{4}{|c|}{ Assurance } \\
\hline$V_{14}$ & the ability of employees to build trust with customers & 0.035 & 0.000 \\
\hline$V_{15}$ & the ability of employees to make their clients feel comfortable & 0.003 & 0.579 \\
\hline$V_{16}$ & consistent politeness from company employees & 0.005 & 0.009 \\
\hline$V_{17}$ & qualified staff that can answer all customer questions & 0.024 & 0.054 \\
\hline \multicolumn{4}{|c|}{ Empathy } \\
\hline$V_{18}$ & company's individual attention to customers & 0.047 & 0.167 \\
\hline$V_{19}$ & employee's personalized services and attention to their clients & 0.161 & 0.163 \\
\hline$V_{20}$ & employee's focus on customer interest & 0.008 & 0.090 \\
\hline$V_{21}$ & employee's understanding of customer needs & 0.002 & 0.023 \\
\hline$V_{22}$ & logistics company's working hours & 0.065 & 0.610 \\
\hline
\end{tabular}




\subsubsection{Expectation analysis}

Calculating the ANOVA, see Appendix, it was found that the expectations for reliability do not differ between customers of logistics companies (Sig. $=0.614$, greater than $0.05)$. On closer inspection of the other tests, the post hoc test values showed that there is no difference in the expectations of representatives of customers trading in the categories of everyday consumer goods and luxury goods, or those in everyday consumer goods and construction and other raw materials categories, or those in luxury goods and construction and other raw materials categories (all in pairs). Table 4 also shows that the importance of statements on all five criteria are equally significant (all Sig. values were greater than 0.05 ). The highest score (comparing not only reliability but all 22 statements) is for the statement, "delivering the logistics service as promised".

It can thus be concluded that reliability is an equally significant factor for all representatives from all of the product categories investigated. An essential criterion for the quality of logistics services is the ability to deliver the service as promised.

Respondents' lowest expectations were in terms of tangibles. It was ranked worst by businesses in construction and other raw materials (3.04). The ANOVA values calculated showed that customer expectations for logistics companies in terms of tangibles differ significantly (Sig. = 0.000 , less than 0.05 ).

Post hoc tests showed a significant difference between the consumer goods category and the category of construction and other raw materials (Sig. $=0.000$, less than 0.05 ) and between the luxury goods category and the category of construction and other raw materials (Sig. $=0.000$, less than 0.05). Representatives of customers trading in the everyday consumer goods category and the luxury goods category rated tangibles statistically equally (Sig. = 0.866 , greater than 0.05 ).

The importance of the first three statements on tangibles - "well-maintained, cutting-edge equipment", "comfortable working environment and infrastructure", and "neat, professional-looking staff" - is significantly different. For the categories of everyday consumer goods and luxury goods, these three criteria are equally statistically significant. Their importance is less significant for the construction and other raw materials category. Only one criterion, "clear and correct company documents", is equally important for all representatives of customers trading in the three product categories. This means that, despite the lowest expectations for tangibles, logistics companies must ensure clear, correct presentation of documents to their customers.

The values obtained for the three remaining factors follow. In all three comparative categories, customer expectations for logistics companies in terms of responsiveness do not differ (Sig. $=0.137$, greater than 0.05$)$. Consequently, logistics companies may respond similarly to the demands of their customers.
Customer expectations for logistics companies in terms of assurance differ significantly (Sig. $=0.003$, less than 0.05). This factor is ranked second-lowest after tangibles. Its importance differs only between the luxury goods category and the category of construction and other raw materials (Sig. $=0.005$, less than 0.05) (post hoc test data).

Customer expectations for logistics companies in terms of empathy differ significantly (Sig. $=0.006$, less than 0.05). However, after checking the post hoc test data, we found that empathy is rated statistically equally among all respondents (a difference is present for respondents working in the discarded product categories).

\subsubsection{Perception analysis}

The data in Table 4 suggests that logistics business customers are most satisfied with the quality of the responsiveness factor. The quality of this factor satisfied respondents in the category of everyday consumer goods the most. ANOVA and other post hoc tests showed that representatives from all of the categories were statistically equally satisfied with the responsiveness factor (Sig. $=0.976$, greater than 0.05). Individual statements related to this factor and their Sig. values also indicate that respondents' satisfaction with logistics services in terms of responsiveness is statistically equal. This shows that, at this time, logistics companies can best respond to customer needs, i.e. logistics companies' employees are prepared to provide customers with services, respond to their requests, keep them informed on the progress of the services, and so on.

The second-place factor, according to the respondents' satisfaction, is assurance. This factor's quality was also most highly-rated by respondents from the category of everyday consumer goods. Respondents' satisfaction with this factor differed significantly (Sig. $=0.034$, less than 0.05 ). The values from the two tests, Bonfferoni and Games-Howell, showed that satisfaction with this factor among respondents from the categories of everyday consumer goods and luxury goods was statistically significantly different (Sig. = 0.041 and Sig. $=0.048$, less than 0.05). Representatives from the other categories are equally statistically satisfied with the quality of this factor.

Respondents are relatively satisfied with two criteria regarding assurance. Luxury companies are the least satisfied with employees' ability to establish a sense of trust with their customers. Thus, when it comes to working with luxury goods, assurance is a crucial factor in the quality of logistics services.

Logistics companies' customers are least satisfied with the quality of the tangibles factor. However, this factor's importance to respondents in terms of expectations is also the least significant, which may mean they are less likely to value their satisfaction. The least satisfaction with this factor was found among companies engaged in luxury goods. Logistics companies should, therefore, pay more attention to their existing infrastructure, work environment, and staff and improve the quality of these indicators. 
Respondents' satisfaction with tangibles differed significantly (Sig. $=0.009$, less than 0.05). However, differences in satisfaction are only found between the categories of everyday consumer goods and luxury goods (Sig. $=0.012$, less than 0.05) (post hoc test data). According to separate criteria for the tangibles factor, respondents are not equally satisfied with the following criteria, which determine the quality of logistics services: "well-maintained, cuttingedge equipment" and "comfortable working environment and infrastructure". Businesses working with luxury goods are the least satisfied with the quality of these two criteria. Thus, to satisfy companies working in luxury goods, logistics service providers need to have modern equipment, as well as a working environment and infrastructure that corresponds to customer needs.

Respondents' satisfaction with the quality of the remaining two factors, reliability and empathy, is not statistically different (Sig. $=0.314$ and Sig. $=0.212$, greater than 0.05).

\subsubsection{Gap analysis}

Figure 2 shows the mean values of the gaps between expectations and perceptions for each factor of the SERVQUAL model. If the value is negative, then customer expectations exceed the quality of service currently received. If the value is positive, customer needs are met in a manner that surpasses expectations (or ranking of importance).

The largest gap between the three categories of goods compared was between customer expectations and perceptions in terms of reliability in logistics services. The overall difference between representatives' expectations and perceptions in all three product categories is -3.85 .

As a result, the study identifies the largest gap between the logistics service providers' ability and customer needs in the following areas: delivering the logistics service as promised, performing the service well the first time, and doing so within the scheduled timeframe. These criteria were the least satisfying. Respondents were satisfied with only one of the criteria for quality of the logistics services: "presentation of documents, records, and other informa- tion with no errors". This means that logistics companies provide their customers with correct and error-free documentation.

The smallest gap between customer expectations and perceptions in logistics services quality is in tangibles. As shows the Table 5, the lowest level of satisfaction with this factor is in the luxury goods category $(-0.77)$. However, companies working with construction and other raw materials identified this single factor as surpassing their expectations in terms of satisfaction (0.48). Thus, for companies working in construction and other raw materials, the relevant criteria, "well-maintained, cuttingedge equipment", "comfortable working environment and infrastructure", and "neat, professional-looking staff" are the least important factors in determining the quality of logistics services.

The remaining three factors, responsiveness, assurance, and empathy, all have negative values, meaning that logistics companies are unable to meet the needs of these customers fully.

More significant observations include the quality of the two assurance criteria: "the ability of employees to make their clients feel comfortable" and "consistent politeness from company employees". These criteria were more satisfying than expected among companies in the construction and other raw materials category. Hence, courtesy among employees and their ability to create a sense of comfort are of little importance to companies in the category of construction and other raw materials. This is unlike companies in the luxury goods category, which consider the ability to build trust in logistics companies in order to outsource storage, transportation, etc. of expensive goods as very important.

Quality for one of the empathy factors, "understanding customer needs", is equally statistically significant to all representatives of customers trading in the comparative product categories. In addition, the gap size between expectations and perceptions in terms of this factor's quality is the greatest. As such, logistics companies are unable to understand and meet all customer needs fully.

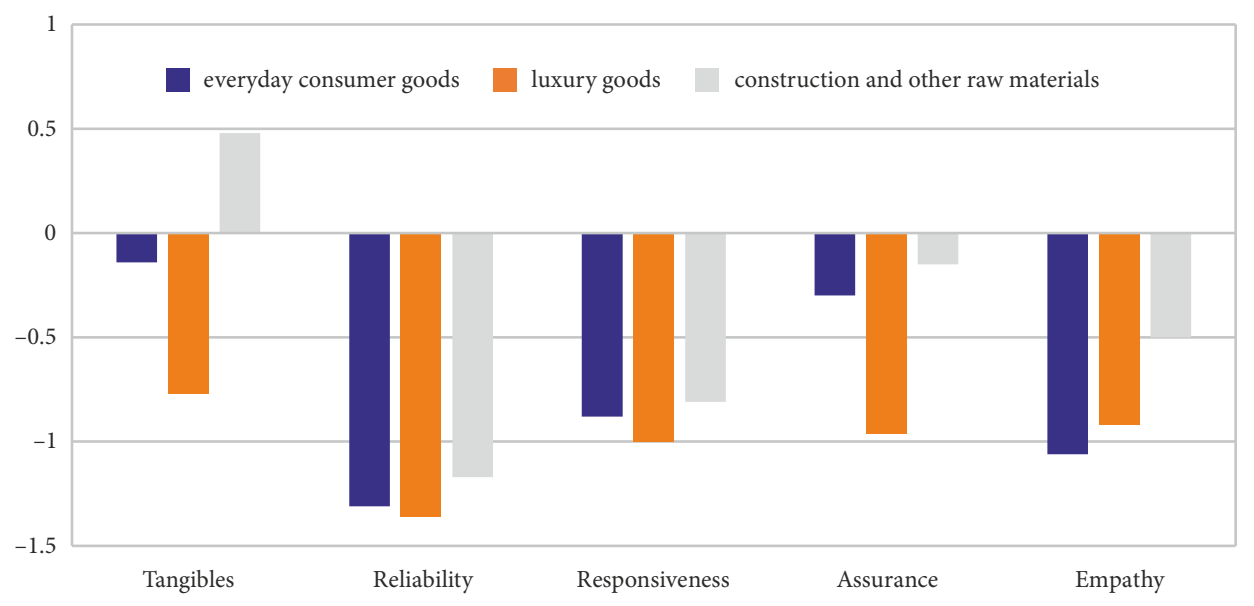

Figure 2. Mean values of the gaps by product category (source: compiled by authors) 
Table 5. SERVQUAL criteria meaning (total and average) (source: compiled by authors)

\begin{tabular}{|l|c|c|c|}
\hline \multirow{2}{*}{ Criteria } & \multicolumn{3}{|c|}{ Gap } \\
\cline { 2 - 4 } & $\begin{array}{c}\text { Everyday } \\
\text { consumer } \\
\text { goods }\end{array}$ & $\begin{array}{c}\text { Luxury } \\
\text { goods }\end{array}$ & $\begin{array}{c}\text { Construction } \\
\text { and other raw } \\
\text { materials }\end{array}$ \\
\hline Tangibles & -0.14 & -0.77 & 0.48 \\
\hline Reliability & -1.31 & -1.36 & -1.17 \\
\hline Responsiveness & -0.88 & -1.01 & -0.81 \\
\hline Assurance & -0.30 & -0.96 & -0.15 \\
\hline Empathy & -1.06 & -0.92 & -0.50 \\
\hline In total: & -3.69 & -5.02 & -2.15 \\
\hline Average: & -0.74 & -1.00 & -0.43 \\
\hline
\end{tabular}

The study found the largest gap between expectations and reported perceptions among the representatives of customers in the luxury goods category $(-5.02)$. This shows that their satisfaction with the quality of logistics services is the lowest, compared to their own expectations.

The smallest gap was found between customer representatives from the category of construction and other raw materials $(-2.15)$. This shows that their satisfaction with the quality of logistics services is the highest, compared to their own expectations.

From this analysis, we can confirm that the third hypothesis $\left(\mathrm{H}_{3}\right)$ is accurate: representatives of customers trading in different categories of goods are not equally satisfied with the quality of logistics services. Therefore, logistics companies do indeed need to tailor their services to the needs of companies in different product categories.

Other hypotheses that have been confirmed:

- $\mathrm{H}_{4}$ : representatives of customers trading in different categories of goods are not equally satisfied with the quality of the tangibles factor;

- $H_{7}$ : representatives of customers trading in different categories of goods are not equally satisfied with the quality of the assurance factor.
Hypotheses rejected:

- $H_{5}$ : representatives of customers trading in different categories of goods are not equally satisfied with the quality of the reliability factor. Consequently, respondents' satisfaction with the quality of the reliability factor is not statistically different (or their satisfaction is statistically equal) among the representatives of all three categories of goods compared;

- $\mathrm{H}_{6}$ : representatives of customers trading in different categories of goods are not equally satisfied with the quality of the responsiveness factor. Consequently, the respondents' satisfaction with the quality of the responsiveness factor is not statistically different (or their satisfaction is statistically equal) among the representatives of all three categories of goods compared;

- $\mathrm{H}_{8}$ : representatives of customers trading in different categories of goods are not equally satisfied with the quality of the empathy factor. Consequently, respondents' satisfaction with the quality of the empathy factor is not statistically different (or their satisfaction is statistically equal) among the representatives of all three categories of goods compared.

\subsubsection{Overall importance of logistics services}

During the survey, respondents were asked to collectively evaluate five logistics service quality criteria: "good/clear visibility of logistics service elements", "logistics service provider's ability to deliver the promised service on time the first time", "the ability of the logistics service provider's staff to serve the client and deliver service urgently", "the logistics service provider's ability to establish a sense of trust and confidence", "caring and individual attention of the logistics company staff to each customer". The rating ranged from 1 (least important) to 5 (most important). Figure 3 and Table 6 presents the results of this evaluation. Only the most important rating, 5 points, is analysed. Figure 3 shows the number of respondents from each product category who rated each statement by 5 points. Table 6 represents these values converted into percentages.

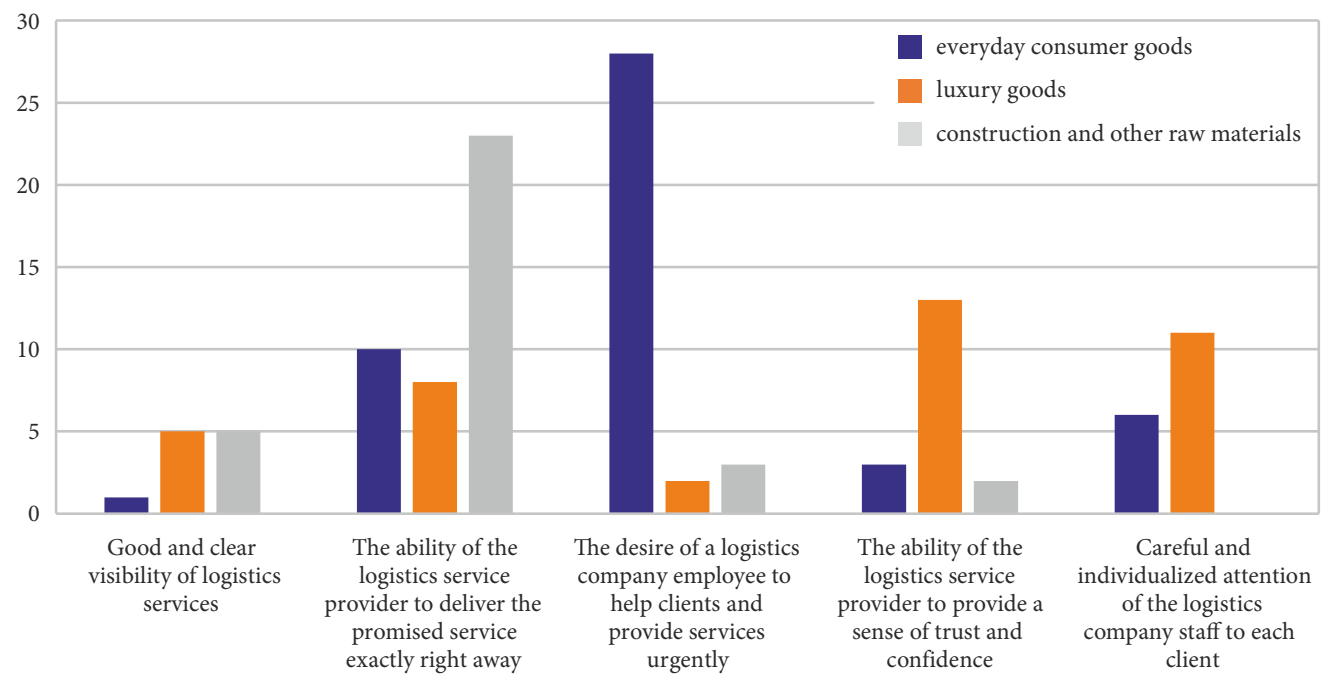

Figure 3. Overall ranking of logistics service criteria by importance (source: compiled by authors) 
The Kruskal-Wallis test examined whether there was a difference in the assessment of each item in the comparative product categories. Respondents equally statistically rated "good/clear visibility of logistic service elements" (Sig. $=0.053$, greater than 0.05) and "caring and individual attention of the logistics company staff for each customer" $($ Sig. $=0.154$, greater than 0.05$)$.

The importance of three criteria - "the logistics service provider's ability to deliver the promised service on time the first time"; "the ability of the logistics service provider's staff to serve the client and deliver service urgently", and "the logistics service provider's ability to establish a sense of trust and confidence" - was statistically different among respondents.

Table 7 shows the values obtained by averaging the significance and importance of each gap in the SERVQUAL model. For example, the first value, -0.003 , was obtained by multiplying the mean of the gap and the importance as a percentage $(-0.14 \cdot 2.1 \%=-0.003 \%)$.

Table 6. Overall ranking of logistics service criteria by importance (percentage) (source: compiled by authors)

\begin{tabular}{|l|c|c|c|c|}
\hline \multicolumn{1}{|c|}{ Criterion } & \multicolumn{2}{|c|}{ Most important (5) [\%] } \\
\cline { 2 - 5 } & $\begin{array}{c}\text { Everyday } \\
\text { consumer goods }\end{array}$ & $\begin{array}{c}\text { Luxury goods } \\
\text { Construction } \\
\text { and other raw } \\
\text { materials }\end{array}$ & $\begin{array}{c}\text { The overall } \\
\text { importance of } \\
\text { the criterion }\end{array}$ \\
\hline Good/clear visibility of logistics service elements & 2.1 & 12.8 & 12.5 & 9.1 \\
\hline $\begin{array}{l}\text { Logistics service provider's ability to deliver the promised } \\
\text { service on time the first time }\end{array}$ & 20.8 & 20.5 & 57.5 & 32.9 \\
\hline $\begin{array}{l}\text { Ability of the logistics service provider's staff to serve the } \\
\text { client and deliver service urgently. }\end{array}$ & 58.3 & 5.2 & 7.5 & 23.7 \\
\hline $\begin{array}{l}\text { Logistics service provider's ability to establish a sense of trust } \\
\text { and confidence }\end{array}$ & 6.3 & 33.3 & 5.0 & 14.9 \\
\hline $\begin{array}{l}\text { Caring and individual attention of the logistics company staff } \\
\text { for each customer }\end{array}$ & 12.5 & 28.2 & 17.5 & 19.4 \\
\hline \multicolumn{1}{|c|}{ In total } & 100.0 & 100.0 & 100.0 & 100.0 \\
\hline
\end{tabular}

Table 7. "Weights" for average gap values and overall values for logistics service quality (source: compiled by authors)

\begin{tabular}{|c|c|c|c|c|c|c|c|c|c|}
\hline \multirow{3}{*}{ Criterion } & \multicolumn{9}{|c|}{ Most important (5) } \\
\hline & \multicolumn{3}{|c|}{ Everyday consumer goods } & \multicolumn{3}{|c|}{ Luxury goods } & \multicolumn{3}{|c|}{$\begin{array}{l}\text { Construction and other raw } \\
\text { material }\end{array}$} \\
\hline & $\begin{array}{c}\text { Importance } \\
{[\%]}\end{array}$ & $\begin{array}{l}\text { Gap } \\
\text { average }\end{array}$ & Value & $\begin{array}{c}\text { Importance } \\
{[\%]}\end{array}$ & $\begin{array}{l}\text { Gap } \\
\text { average }\end{array}$ & Meaning & $\begin{array}{c}\text { Importance } \\
{[\%]}\end{array}$ & $\begin{array}{l}\text { Gap } \\
\text { average }\end{array}$ & Value \\
\hline $\begin{array}{l}\text { Good/clear visibility } \\
\text { of logistics service } \\
\text { elements }\end{array}$ & 2.1 & -0.14 & -0.003 & 12.8 & -0.77 & -0.099 & $12.5 \%$ & 0.48 & 0.060 \\
\hline $\begin{array}{l}\text { Logistics service } \\
\text { provider's ability to } \\
\text { deliver the promised } \\
\text { service on time the } \\
\text { first time }\end{array}$ & 20.8 & -1.31 & -0.273 & 20.5 & -1.36 & -0.280 & $57.5 \%$ & -1.17 & -0.673 \\
\hline $\begin{array}{l}\text { Ability of the } \\
\text { logistics service } \\
\text { provider's staff to } \\
\text { serve the client } \\
\text { and deliver service } \\
\text { urgently }\end{array}$ & 58.3 & -0.88 & -0.513 & 5.2 & -1.01 & -0.052 & 7.5 & -0.81 & -0.061 \\
\hline $\begin{array}{l}\text { Logistics service } \\
\text { provider's ability to } \\
\text { establish a sense of } \\
\text { trust and confidence. }\end{array}$ & 6.3 & -0.30 & -0.019 & 33.3 & -0.96 & -0.318 & 5.0 & -0.15 & -0.007 \\
\hline $\begin{array}{l}\text { Caring and } \\
\text { individual attention } \\
\text { of the logistics } \\
\text { company staff for } \\
\text { each customer }\end{array}$ & 12.5 & -1.06 & -0.133 & 28.2 & -0.92 & -0.261 & 17.5 & -0.50 & -0.088 \\
\hline In total & 100.0 & -3.69 & -0.941 & 100.0 & -5.02 & -1.009 & 100.0 & -2.15 & -0.769 \\
\hline
\end{tabular}


With a significance of -0.513 , the responsiveness factor is the most important for the everyday consumer goods category. For the luxury goods category, it is the factor of assurance with a significance of -0.318 . Respondents in the category of construction and other raw materials consider reliability to be the most important factor with a significance of -0.673 .

By comparing all five criteria - tangibles, reliability, responsiveness, assurance, and empathy - we can see that reliability is the most important factor for the quality of logistics services among logistics companies' customers with an overall ranking of $32.9 \%$ (Table 6). The least significant factor is Tangibles, with a ranking of $9.1 \%$.

\section{Conclusions and suggestions}

In order to evaluate the quality of logistics services in Lithuanian companies, a survey was conducted to determine the expectations of logistics companies' customers and their satisfaction with the quality of services. The quality of five factors from the SERVQUAL model - tangibles, reliability, responsiveness, assurance, and empathy - were surveyed among respondents from three product categories: everyday consumer goods, luxury goods, and construction and other raw materials.

The investigation found that logistics companies' customers have the highest expectations for reliability and the lowest for tangibles. Logistics companies' customers are also most satisfied with the quality of reliability. This means that even if companies that outsource logistics services to third parties have the highest demands for reliability, they still rank their satisfaction with reliability the highest.

When the expectations for service quality were compared, it was found that logistics companies' customers rank their expectations for all factors above the quality actually obtained. This means that logistics companies are not able to meet all customer needs fully.

After analysing the overall assessment data for tangibles, it was found that clear, correct presentation of documents has the greatest impact on the quality of logistics services. In terms of reliability, the logistics company's ability to perform the service well the first time, in the timeframe given, and as promised was found to be most important to the logistics outsourcing company. Analysis of the responsiveness factor showed that logistics companies' customers consider being provided with service quickly and accurately is of the utmost importance. Analysis of evaluation data on the assurance factor shows that the quality of logistics services is primarily influenced by the logistics company's personnel being qualified and able to answer all of the customer's questions. After evaluating the empathy factor, it was found that respondents value logistics companies' employees who understand their customers' needs.
In order to determine which of the SERVQUAL model's five factors is most important in assessing the quality of the logistics service, an overall analysis of the logistics service evaluation was conducted for each category of goods. The results were compared to the gap values, and the most important factors for customer satisfaction were obtained. The willingness of the logistics company's employees to assist their customers and provide their services promptly (that is, responsiveness) was identified as a key element for the everyday consumer goods category. For the luxury goods category, the most important factor was assurance - having confidence in the logistics company. Representatives from the category of construction and other raw materials want all materials to be delivered on time the first time, as promised (reliability).

By comparing all five factors from the SERVQUAL model - tangibles, reliability, responsiveness, assurance, and empathy - reliability was found to be the most important factor in the overall quality of logistics services among all logistics companies' customers. Thus, logistics companies should focus on improving the reliability of their services to best meet the needs of their different customers.

To conclude with, the results of the conducted study are important from the point of view of methodological knowledge and practical application. Application of SERVQUAL methodology in case of multitude companies reveals sectoral competitiveness and attractiveness of logistics services to different categories of customers. Based on that, strategic decisions related to expansion of logistics services to target markets can be implemented. The same studies conducted periodically would show exact changes in customer's expectations, and even in current conditions of world-wide pandemic would reveal new customer's expectations towards the logistics services they are looking for.

\section{Author contributions}

Ieva Meidutè-Kavaliauskienè and Virgilija VasilienèVasiliauskienè conceived the study and were responsible for the design and development of the data analysis.

Ieva Meidutè-Kavaliauskiené, Aidas Vasilis Vasiliauskas and Virgilija Vasiliené-Vasiliauskienè were responsible for data collection and analysis.

Virgilija Vasiliené-Vasiliauskienè was responsible for data interpretation.

Ieva Meidute-Kavaliauskienè wrote the first draft of the article.

Virgilija Vasilienè-Vasiliauskienè was responsible for investigation and resources.

Virgilija Vasiliené-Vasiliauskienė and Ieva MeidutèKavaliauskienè were responsible for writing - review and editing. 


\section{Appendix. ANOVA results}

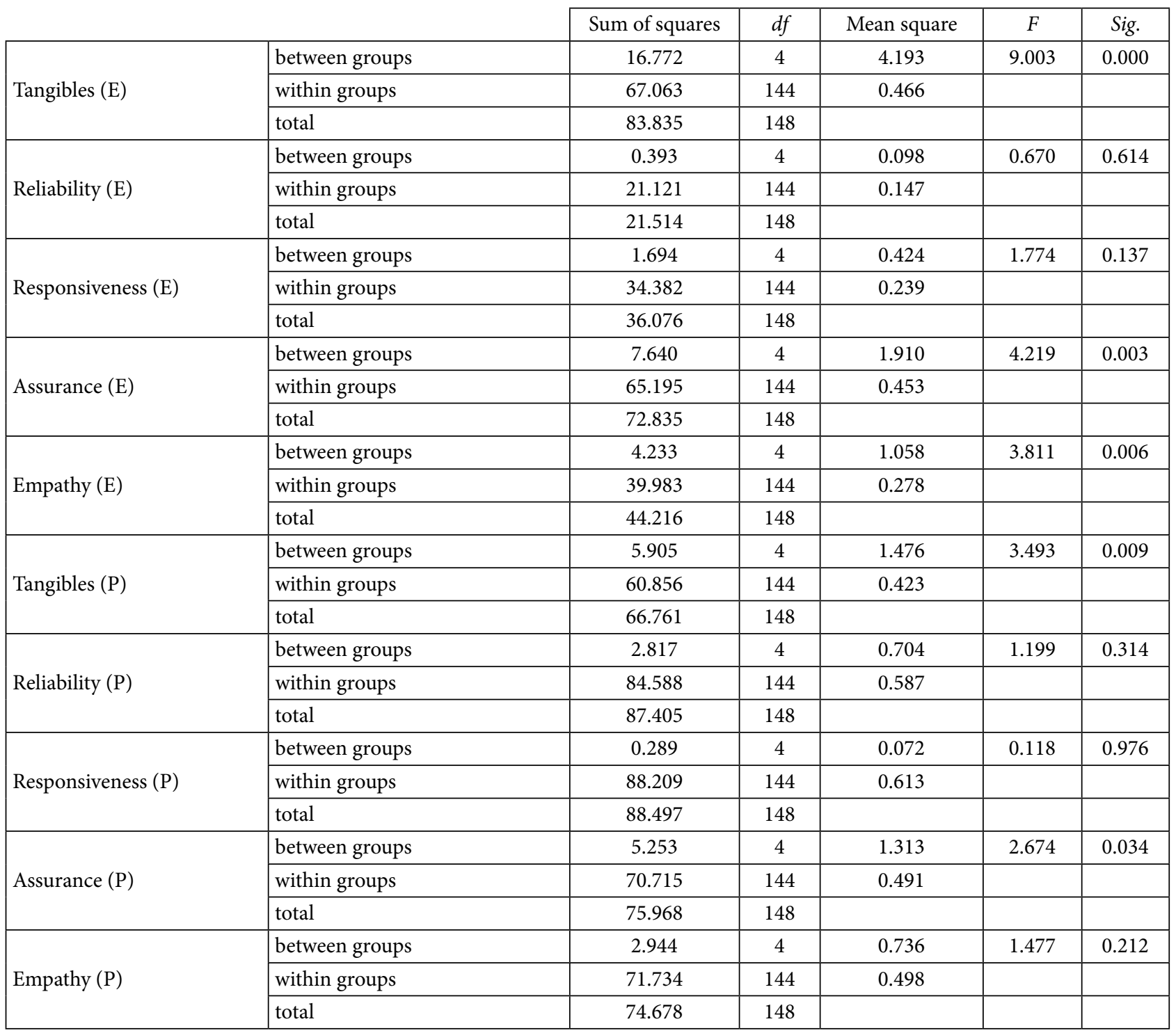

\section{References}

Aggarwal, S.; Gupta, A.; Govindan, K.; Jha, P. C.; Meidute, I. 2014. Effect of repeat purchase and dynamic market size on diffusion of an innovative technological consumer product in a segmented market, Technological and Economic Development of Economy 20(1): 97-115.

https://doi.org/10.3846/20294913.2014.885914

Agnihotri, R.; Dingus, R.; Hu, M. Y.; Krush, M. T. 2016. Social media: influencing customer satisfaction in B2B sales, Industrial Marketing Management 53: 172-180.

https://doi.org/10.1016/j.indmarman.2015.09.003

Ahn, K.; Kim, M.; Kim, B. 2008. The study of the effect of container terminal service quality on customer satisfaction and loyalty: the moderating effect of the company size and port location, Korean Management Review 37(3): 417-442. (in Korean).

Al-Jazzazi, A.; Sultan, P. 2017. Demographic differences in Jordanian bank service quality perceptions, International Journal of Bank Marketing 35(2): 275-297.

https://doi.org/10.1108/IJBM-07-2016-0091
Ali, M.; Raza, S. A. 2017. Service quality perception and customer satisfaction in Islamic banks of Pakistan: the modified SERVQUAL model, Total Quality Management \& Business Excellence 28(5-6): 559-577.

https://doi.org/10.1080/14783363.2015.1100517

An, U.-S. 2004. A study on the logistics service quality, customer satisfaction, relationship quality and repurchase intention in internet shopping mall, Journal of Korean Society for Quality Management 32(4) 30-47. (in Korean).

Anderson, E. W.; Fornell, C.; Lehrmann, D. R. 1994. Customer satisfaction, market share, and profitability: findings from Sweden, Journal of Marketing 58(3): 53-66.

https://doi.org/10.2307/1252310

Babakus, E.; Boller, G. W. 1992. An empirical assessment of the SERVQUAL scale, Journal of Business Research 24(3): 253268. https://doi.org/10.1016/0148-2963(92)90022-4

Baki, B.; Sahin Basfirinci, C.; Murat, I.; Cilingir, Z. 2009. An application of integrating SERVQUAL and Kano's model into QFD for logistics services: a case study from Turkey, Asia $\mathrm{Pa}$ cific Journal of Marketing and Logistics 21(1): 106-126. https://doi.org/10.1108/13555850910926272 
Banomyong, R.; Supatn, N. 2011. Selecting logistics providers in Thailand: a shippers' perspective, European Journal of Marketing 45(3): 419-437.

https://doi.org/10.1108/03090561111107258

Bienstock, C. C.; Mentzer, J. T.; Bird, M. M. 1997. Measuring physical distribution service quality, Journal of the Academy of Marketing Science 25(1): 31-44.

https://doi.org/10.1007/BF02894507

Blut, M.; Frennea, C. M.; Mittal, V.; Mothersbaugh, D. L. 2015. How procedural, financial and relational switching costs affect customer satisfaction, repurchase intentions, and repurchase behavior: a meta-analysis, International Journal of Research in Marketing 32(2): 226-229.

https://doi.org/10.1016/j.ijresmar.2015.01.001

Campos, D. F.; Nóbrega, K. C. 2009. Importance and the zone of tolerance of customer expectations of fast food services, Journal of Operations and Supply Chain Management 2(2): 56-71. https://doi.org/10.12660/joscmv2n2p56-71

Caplice, C.; Sheffi, Y. 1995. A review and evaluation of logistics performance measurement systems, The International Journal of Logistics Management 6(1): 61-74.

https://doi.org/10.1108/09574099510805279

Cepeda-Carrion, I.; Martelo-Landroguez, S.; Leal-Rodríguez, A. L.; Leal-Millán, A. 2017. Critical processes of knowledge management: An approach toward the creation of customer value, European Research on Management and Business Economics 23(1): 1-7. https://doi.org/10.1016/j.iedeen.2016.03.001

Chen, C.-F.; Chen, F.-S. 2010. Experience quality, perceived value, satisfaction and behavioral intentions for heritage tourists, Tourism Management 31(1): 29-35.

https://doi.org/10.1016/j.tourman.2009.02.008

Chen, K.-K.; Chang, C.-T.; Lai, C.-S. 2009. Service quality gaps of business customers in the shipping industry, Transportation Research Part E: Logistics and Transportation Review 45(1): 222-237. https://doi.org/10.1016/j.tre.2008.02.005

Choudhury, K. 2015. Service quality and customers' behavioural intentions: class and mass banking and implications for the consumer and society, Asia Pacific Journal of Marketing and Logistics 27(5): 735-757.

https://doi.org/10.1108/APJML-02-2015-0025

Chumpitaz Caceres, R.; Paparoidamis, N. G. 2007. Service quality, relationship satisfaction, trust, commitment and businessto-business loyalty, European Journal of Marketing 41(7/8): 836-867. https://doi.org/10.1108/03090560710752429

Ciavolino, E.; Calcagnì, A. 2015. Generalized cross entropy method for analysing the SERVQUAL model, Journal of Applied Statistics 42(3): 520-534.

https://doi.org/10.1080/02664763.2014.963526

Dahlgaard-Park, S. M; Dahlgaard, J. J. 2010. Organizational learnability and innovability: a system for assessing, diagnosing and improving innovations, International Journal of Quality and Service Sciences 2(2): 153-174.

https://doi.org/10.1108/17566691011057339

Feng, Y.-X.; Zheng, B.; Tan, J.-R. 2007. Exploratory study of logistics service quality scale based on online shopping malls, Journal of Zhejiang University - Science A 8(6): 926-931. https://doi.org/10.1631/jzus.2007.A0926

Ferreira, F. A. F.; Jalali, M. S.; Meidutè-Kavaliauskienè, I.; Viana, B. A. C. P. 2015. A metacognitive decision making based-framework for bank customer loyalty measurement and management, Technological and Economic Development of Economy 21(2): 280-300.

https://doi.org/10.3846/20294913.2014.981764
Franceschini, F; Rafele, C. 2000. Quality evaluation in logistic services, International Journal of Agile Management Systems 2(1): 49-54. https://doi.org/10.1108/14654650010312589

Ganesan-Lim, C.; Russell-Bennett, R.; Dagger, T. 2008. The impact of service contact type and demographic characteristics on service quality perceptions, Journal of Services Marketing 22(7): 550-561. https://doi.org/10.1108/08876040810909677

Grönroos, C. 1984. A service quality model and its marketing implications, European Journal of Marketing 18(4): 36-44. https://doi.org/10.1108/EUM0000000004784

Hong, S.; Lyong, C. 2008. An empirical study on the relationship between logistics service quality and customer satisfaction of on-line shopping in China, Journal of e-Business 9(4): 267-288. (in Korean).

https://doi.org/10.15719/geba.9.4.200811.267

Huang, B.; Wang, T.; Xue, X. 2012. Service-selecting approach based on domain-specified 'quality of service' model and its application in logistics, The Service Industries Journal 32(9): 1571-1588. https://doi.org/10.1080/02642069.2010.551761

İnan, U. H.; Gül, S.; Yılmaz, H. 2017. A multiple attribute decision model to compare the firms' occupational health and safety management perspectives, Safety Science 91: 221-231. https://doi.org/10.1016/j.ssci.2016.08.018

Jia, P.; Mahdiraji, H. A.; Govindan, K.; Meidute, I. 2013. Leadership selection in an unlimited three-echelon supply chain, Journal of Business Economics and Management 14(3): 616637. https://doi.org/10.3846/16111699.2012.761648

Juga, J.; Juntunen, J.; Grant, D. B. 2010. Service quality and its relation to satisfaction and loyalty in logistics outsourcing relationships, Managing Service Quality: an International Journal 20(6): 496-510. https://doi.org/10.1108/09604521011092857

Kansra, P.; Jha, A. K. 2016. Measuring service quality in Indian hospitals: an analysis of SERVQUAL model, International Journal of Services and Operations Management 24(1): 1-17. https://doi.org/10.1504/IJSOM.2016.075761

Kaynak, H. 2003. The relationship between total quality management practices and their effects on firm performance, Journal of Operations Management 21(4): 405-435. https://doi.org/10.1016/S0272-6963(03)00004-4

Kaynak, H.; Hartley, J. L. 2008. A replication and extension of quality management into the supply chain, Journal of Operations Management 26(4): 468-489.

https://doi.org/10.1016/j.jom.2007.06.002

Kersten, W.; Koch, J. 2010. The effect of quality management on the service quality and business success of logistics service providers, International Journal of Quality \& Reliability Management 27(2): 185-200.

https://doi.org/10.1108/02656711011014302

Kilibarda, M.; Zečević, S.; Vidović, M. 2012. Measuring the quality of logistic service as an element of the logistics provider offering, Total Quality Management \& Business Excellence 23(11/12): 1345-1361.

https://doi.org/10.1080/14783363.2012.704279

Kim, D.-Y.; Kumar, V.; Kumar, U. 2012. Relationship between quality management practices and innovation, Journal of $\mathrm{Op}$ erations Management 30(4): 295-315.

https://doi.org/10.1016/j.jom.2012.02.003

Lao, S. I.; Choy, K. L.; Ho, G. T. S.; Tsim, Y. C.; Chung, N. S. H. 2011. Determination of the success factors in supply chain networks: a Hong Kong-based manufacturer's perspective, Measuring Business Excellence 15(1): 34-48. https://doi.org/10.1108/13683041111113231 
Mckinnon, A. C.; Mendes, D.; Nababteh, M. 2007. In-store logistics: an analysis of on-shelf availability and stockout responses for three product groups, International Journal of Logistics Research and Applications: a Leading Journal of Supply Chain Management 10(3): 251-268.

https://doi.org/10.1080/13675560701478075

Mentzer, J. T.; Flint, D. J.; Hult, T. M. 2001. Logistics service quality as a segment-customized process, Journal of Marketing 65(4): 82-104. https://doi.org/10.1509/jmkg.65.4.82.18390

Neo, H.-Y.; Xie, M.; Tsui, K.-L. 2004. Service quality analysis: case study of a 3PL company, International Journal of Logistics Systems and Management 1(1): 64-80. https://doi.org/10.1504/IJLSM.2004.005539

Pantouvakis, A.; Chlomoudis, C.; Dimas, A. 2008. Testing the SERVQUAL scale in the passenger port industry: a confirmatory study, Maritime Policy \& Management: the Flagship Journal of International Shipping and Port Research 35(5): 449-467. https://doi.org/10.1080/03088830802352095

Plakoyiannaki, E.; Zotos, Y. 2009. Female role stereotypes in print advertising: Identifying associations with magazine and product categories, European Journal of Marketing 43(11/12): 1411-1434. https://doi.org/10.1108/03090560910989966

Prentkovskis, O.; Erceg, Ž.; Stević, Ž.; Tanackov, I.; Vasiljević, M.; Gavranović, M. 2018. A new methodology for improving service quality measurement: Delphi-FUCOM-SERVQUAL model, Symmetry 10(12): 757.

https://doi.org/10.3390/sym10120757

Rahman, S. 2006. Quality management in logistics: an examination of industry practices, Supply Chain Management 11(3): 233-240. https://doi.org/10.1108/13598540610662130

Subramanian, N.; Gunasekaran, A.; Gao, Y. 2016. Innovative service satisfaction and customer promotion behaviour in the Chinese budget hotel: an empirical study, International Journal of Production Economics 171: 201-210. https://doi.org/10.1016/j.ijpe.2015.09.025

Sureshchandar, G. S.; Rajendran, C.; Anantharaman, R. N. 2002. The relationship between service quality and customer satisfaction - a factor specific approach, Journal of Services Marketing 16(4): 363-379. https://doi.org/10.1108/08876040210433248

Tate, K. 1996. The elements of a successful logistics partnership, International Journal of Physical Distribution \& Logistics Management 26(3): 7-13.

https://doi.org/10.1108/09600039610115045

Ugboma, C.; Ogwude, I. C.; Ugboma, O.; Nnadi, K. 2007. Service quality and satisfaction measurements in Nigerian ports: an exploration, Maritime Policy \& Management: the Flagship Journal of International Shipping and Port Research 34(4): 331-346. https://doi.org/10.1080/03088830701539073

Zanjirani, D. M.; Hashemkhani Zolfani, S.; Prentkovskis, O. 2019. L.A.R.G. supplier selection based on integrating house of quality, Taguchi loss function and M.O.P.A., Economic Research - Ekonomska Istraživanja 32(1): 1944-1964.

https://doi.org/10.1080/1331677X.2019.1635036 